\title{
AUDIT DELAY DAN TIMELINESS DIMODERASI OLEH PROFITABILITAS
}

\author{
Solikhul Hidayat ${ }^{1}$ Muhammad Ridho ${ }^{2}$ Jumaiyah $^{3}$ \\ Jurusan Akuntansi Universitas Islam Nahdlatul Ulama Jepara \\ ${ }^{1}$ solikhulhidayat@unisnu.ac.id \\ ${ }^{2}$ muhammadridho80@gmail.com \\ ${ }^{3}$ mayawahidah@unisnu.ac.id
}

\begin{abstract}
ABSTRAK
Tujuan dari penelitian ini untuk menganalisis pengaruh faktor internal seperti tingkat Solvabilitas, Internal Auditor dan Ukuran Perusahaan, sedangkan dari sisi Eksternal Ukuran Kantor Akuntan Publik terhadap Audit Delay dan Timeliness yang di moderasi oleh Profitabilitas pada perusahaan Consumer Goods yang terdaftar di BEI tahun 2013 - 2017. Metode penelitian menggunakan metode kuantitatif dengan pengumpulan data purposive sampling. Sebanyak 50 perusahaan digunakan sebagai sampel dalam penelitian ini. Hasil penelitian menunjukan bahwa profitabilitas rendah maupun tinggi perusahaan akan tetap melaporkan keuanganya tepat waktu. Sementara ukuran KAP tidak berpengarug terhadap Timeliness. Tinggi rendahnya rasio solvabilitas tidak mempengaruhi audit Delay. Hal ini dapat membantu profesi akuntan publik dalam upaya meningkatkan efisiensi dan efektivitas proses audit dengan mengendalikan faktor-faktor dominan yang menyebabkan terjadinya Audit Delay dan Timeliness
\end{abstract}

Kata Kunci: Internal and External Factors of the Company, Audit Delay and Timeliness, Profitability moderation

\section{ABSTRACT}

The purpose of this study is to analyze internal factors such as the level of Solvency, Internal Auditors and Company Size, while from the External side the Size of the Public Accounting Firm on Audit Delay and Timeliness moderated by Profitability in Consumer Goods companies related to the Indonesia Stock Exchange in the year 2013 - 2017. The research method uses quantitative methods by collecting purposive sampling data. A total of 50 companies were used as samples in this study. The results show that low or high profit companies will continue to report their finances on time. While the KAP size has no effect on Timeliness. High and low solvency ratios do not affect the audit delay. This can help improve public accountability in improving efficiency and improving the audit process by controlling the dominant factors that cause an increase in Audit Delay and Timeliness.

Keywords: Internal and External Factors of the Company, Audit Delay and Timeliness, Profitability moderation

\section{PENDAHULUAN}

\subsection{Latar Belakang}

Kebutuhan akan informasi yang dapat disajikan secara akurat dan tepat sangat penting bagi pemakai laporan keuangan, informasi menjadi tidak bermanfaat andai disajikan tidak secara 
akurat dan tepat waktu, sesuai dengan kesimpulan dari Dyer dan McHugh (1975), menyatakan bahwa ketepatan waktu pelaporan keuangan merupakan unsur pokok bagi sebuah laporan keuangan. Di samping ketepatwaktuan (timeliness), penyampaian laporan keuangan akan memberikan sumbangan kinerja yang efisien di pasar saham sebagai bentuk fungsi evaluasi dan pricing, mengurangi tingkat insider trading dan kebocoran serta isu - isu di pasar saham (Owusu dan Ansah 2000).

Untuk mencapai ketepatwaktuan (timeliness) terutama dalam penyajian laporan auditor independen tidaklah mudah, mengingat semakin berkembangnya perusahaan publik yang ada di Indonesia. Standar Pemeriksaan Akuntan Publik pada standar ketiga yang menyatakan bahwa audit harus dilaksanakan dengan penuh kecermatan dan ketelitian serta pengumpulan alat-alat pembuktian yang cukup memadai (Boynton dan Kell 1996) dalam Rachmawati (2008), ini merupakan hambatan dalam ketepatwaktuan (timeliness) yang harus dihadapi dan hal ini tidaklah mudah,

Dari paparan di atas, penelitian ini bermaksud mengkaji lebih jauh mengenai faktorfaktor yang mempengaruhi audit delay. Faktor-faktor tersebut merupakan hal yang turut pula mempengaruhi ketepatan pelaporan keuangan. Berbagai penelitian mengenai audit delay telah dilakukan, baik di dalam maupun di luar negeri. Penelitian berikut merupakan kelanjutan penelitian-penelitian terdahulu yang telah memperoleh simpulan mengenai faktorfaktor yang mempengaruhi audit delay.

Carslaw dan Kaplan (1991) di New Zealand menguji apakah faktor ukuran perusahaan, jenis industri (finansial dan nonfinansial), pengumuman laba rugi, adanya extraordinary item, jenis opini auditor, tahun buku perusahaan, kepemilikan perusahaan, dan solvabilitas mempengaruhi audit delay. Hasil penelitiannya menunjukkan bahwa hanya dua faktor yang berpengaruh, yakni ukuran perusahaan dan pengumuman rugi.

Mengacu pada penelitian Ashton dkk (1987) di Amerika Serikat, Halim (2000) menguji faktor-faktor yang mempengaruhi audit delay pada perusahaan-perusahaan terdaftar di Bursa Efek Jakarta (BEJ). Halim memaparkan bahwa faktor ukuran perusahaan, jenis industri, tahun buku yang berakhir 31 Desember, opini auditor, tingkat profitabilitas, pengumuman rugi, dan lamanya menjadi klien Kantor Akuntan Publik (KAP) berpengaruh secara serentak terhadap audit delay. Namun saat diuji dengan analisis univariate, faktor yang berpengaruh pada audit delay hanya lama perikatan, tahun buku yang berakhir 31 Desember, dan pengumuman rugi. Berikutnya Subekti dan Widiyanti (2004) mengkaji faktor-faktor 
profitabilitas perusahaan, ukuran perusahaan, sektor industri perusahaan, jenis pendapat akuntan publik, dan ukuran Kantor Akuntan Publik (KAP). Menggunakan sampel tahun 2001 dari perusahaan yang terdaftar di BEJ, kelima faktor tersebut berpengaruh terhadap audit delay. Hasil penelitiannya konsisten dengan hasil penelitian Hanipah (2001), Halim (2000), dan Na'im (1999) (dalam Subekti dan Widiyanti).

Haron dkk (2006) melakukan pula penelitian mengenai karakteristik perusahaan di Indonesia yang diperkirakan berpengaruh terhadap audit delay. Menggunakan sampel penelitian perusahaan manufaktur dan finansial, Haron menguji karakteristik contingent liability, extraordinary item, reputasi Kantor Akuntan Publik, opini auditor, ukuran perusahaan, jenis industri, pengumuman rugi laba, gearing ratio, anak cabang dari perusahaan multinasional, dan good corporate governance. Dari berbagai karakteristik tersebut, ada tiga faktor yang berpengaruh signifikan pada audit delay, ialah opini auditor, jenis industri, dan anak cabang dari perusahaan multinasional. Bagi pihak yang berkepentingan dan yang memerlukan Informasi laporan keuangan, akan merasakan manfaatnya jika laporan keuangan disajikan secara akurat dan tepat pada saat dibutuhkan, kemanfaatan laporan keuangan akan terasa jika dilaporkan secara tepat waktu, hal ini mempuyai nilai dan merupakan faktor yang penting (Givoly dan Palmon 1982) dalam Rachmawati (2008).

Usaha untuk meningkatkkan harga saham perusahaan termasuk prasyarat utamanya adalah penyajian laporan keuangan dan laporan audit (timeliness) secara tepat waktu, Halim (2000). Di sisi lain, proses auditing merupakan kegiatan yang memerlukan waktu yang relatif lama, sehingga adakalanya pengumuman laba dan laporan keuangan menjadi tertunda. Para pelaku bisnis di Pasar Modal berkepentingan dan merasakan manfaat terhadap informasi laporan keuangan auditan yang sudah dipublish, namun lamanya proses penyelesaian audit laporan keuangan, merupakan faktor yang mempengaruhi Audit delay dan Timeliness, hal ini menjadi objek penting untuk diteliti dan dapat dikembangkan lebih lanjut lagi.

Dari faktor internal yang diwakili oleh variabel Solvabilitas, variabel ini sangat penting dalam menilai tingkat kesehatan usaha, karena dapat menunjukan seberapa besar ekuitas perusahaan yang tersedia untuk memberikan jaminan terhadap hutang lancar dan hutang jangka panjang, Firdaus, F. (2014). Perusahaan dengan tingkat kesehatan yang baik akan memberikan keyakinan dan kepercayaan kepada para investornya. 
Keberadaan Internal Auditor sangatlah penting dalam sebuah perusahaan hal ini berkaitan dengan tindak pencegahan kecurangan dalam segala bentuknya dalam setiap aktivitas yang ditelaah langsung merupakan tugas dari Internal Auditor, memeriksa dan mengevaluasi kecukupan struktur pengendalian internal perusahaan dan secara periodik membuat rekomendasi untuk perbaikan-perbaikan yang diperlukan. Akuntan publik sangat membutuhkan peranan dari auditor internal saat proses pengauditan laporan keuangan tahunan, Carslaw dan Kaplan (1991) dalam Rachmawati (2008).

\section{TINJAUAN PUSTAKA}

Ukuran perusahaan merupakan ukuran besar kecilnya sebuah perusahaan yang ditunjukan atau dinilai oleh total asset, total penjualan, jumlah laba, beban pajak dan lainlain, juga didasarkan pada total penjualan, total asset, rata-rata tingkat penjualan (Seftianne, 2011). Ukuran keberhasilan sebuah perusahaan dapat diukur pada tingkat kemampuan perusahaan dalam menghasilkan laba selama periode tertentu dan memberikan gambaran tentang tingkat efektifitas manajemen dalam melaksanakan kegiatan operasinya, hal ini dapat diukur dengan menggunakan Rasio Profitabilitas, rasio ini menunjukkan pengaruh gabungan dari likuiditas, pengelolaan aktiva dan pengelolaan utang terhadap hasil operasi (laba). Bagi pemegang saham, semakin tinggi rasio ini akan semakin baik karena memberikan tingkat kembalian yang lebih besar pada pemegang saham (Firdaus, F : 2014).

Auditing adalah suatu proses sistematis untuk memperoleh dan mengevaluasi bukti secara objektif yang bertujuan untuk menetapkan tingkat kesesuaian antara pernyataanpernyataan tentang kegiatan dan kejadian ekonomi dengan kriteria yang telah ditetapkan dan menyampaikan hasilnya kepada pihak yang berkepentingan (Mulyadi, 2010). Menurut Imam Subekti (2005), Audit Delay adalah lamanya waktu penyelesaian audit yang dilakukan oleh auditor yang diukur dari perbedaan waktu antara tanggal laporan keuangan dengan tanggal opini audit dalam laporan keuangan. Dalam penelitian ini menggunakan laporan keuangan yang memiliki tanggal tutup buku per 31 Desember sampai dengan tanggal diterbitkannya laporan audit.

Audit Delay adalah lamanya hari yang dibutuhkan auditor untuk menyelesaikan pekerjaan auditnya, yang diukur dari tanggal penutupan tahun buku hingga tanggal dipublikasikan laporan keuangan di Bursa Efek Indonesia, (Kusumawardhani, 2013) Audit delay atau sering juga disebut audit report lag merupakan lamanya atau rentang waktu 
penyelesaian audit yang diukur dari tanggal penutupan tahun buku sampai dengan tanggal diterbitkannya laporan. Audit delay untuk setiap perusahaan dapat berbeda karena ada perbedaan lamanya waktu penyelesaian proses audit untuk masing masing perusahaan. Jika jarak waktu ini semakin panjang, ditenggarai bahwa hal ini merupakan indikasi adanya masalah, sehingga terjadi proses negoisasi antara klien dan auditornya mengenai bagaimana menyajikan masalah tersebut di dalam laporan keuangan (Tuanakotta, 2011).

Scott (2003) mendefinisikan informasi sebagai bukti yang mempunyai potensi untuk mempengaruhi keputusan individual. Namun, informasi baru akan bermanfaat bagi pemakainya apabila informasi tersebut tepat waktu. Agar pengambilan keputusan ekonomi cepat dan menghindari tertundanya pengambilan keputusan, maka informasi harus disampaikan sedini mungkin dan tepat waktu. Ketepatwaktuan tidak menjamin relevansi, tetapi relevansi informasi tidak dimungkinkan tanpa ketepatwaktuan informasi mengenai kondisi dan proses perusahaan harus cepat dan tepat sampai kepada pengguna laporan keuangan.

Penelitian tentang Audit delay dan Timeliness telah banyak dilakukan, dengan berbagai faktor yang mempengaruhinya, namun hasilnya masih terdapat perbedaan, dari penelitian sebelumnya hasilnya masih beragam, mungkin dikarenakan sifat variabel independen dan variabel dependen yang diteliti berbeda, beda periode pengamatan, beda jenis pengungkapan dan peraturan yang berlaku dan/atau perbedaan dalam metodologi statistik yang digunakan.

Dari hasil penelitian terdahulu yang telah dilakukan oleh Elia Galuh Candraningtyas et al. 2017, tentang Pengaruh ukuran perusahaan, Profitabilitas, Solvabilitas, dan Ukuran KAP terhadap Audit Delay pada perusahaan consumergoods yang terdaftar di BEI tahun 20122017, hasilnya Ukuran perusahaan berpengaruh negatif, Profitabilitas berpengaruh negatif, Solvabilitas berpengaruh positif dan Ukuran KAP berpengaruh negatif pada Audit Delay. Sementara masih ada hasil penelitian yang berbeda seperti yang dilakukan oleh Sri Wahyuningsih (2015), dimana Profitabilias mempunyai pengaruh signifikan dan Solvabilitas mempunyai pengaruh signifikan terhadap Audit Delay, dari hasil yang berbeda masih menarik untuk dilakukan penelitian kembali.Tujuan penelitian adalah untuk mengetahui: Pengaruh faktor internal perusahaan (solvabilitas, Internal Auditor dan size perusahaan) dan faktor Eksternal perusahaan (ukuran KAP) terhadap Audit Delay dan Timeliness yang di moderasi oleh Profitabilitas. 
Ardianti (2013) menyatakan bahwa solvabilitas merupakan kemampuan suatu perusahaan untuk membayar semua hutang-hutangnya dengan menggunakan modal yang dimilikinya. Dengan semakin tingginya rasio solvabilitas maka semakin tinggi pula resiko kerugian atau kesulitan keuangan yang dihadapi. Wirakusuma (2004) melakukan penelitian yang bertujuan menganalisa faktor-faktor yang mempengaruhi rentang waktu penyajian laporan keuangan ke publik (studi empiris mengenai keberadaan divisi Internal Auditor pada perusahaan perusahaan yang terdaftar di Bursa Efek Jakarta). Adapun hal yang diuji adalah ukuran perusahaan, solvabilitas, jenis industri, Internal Auditor, reputasi auditor, opini auditor dan jumlah waktu pelaksanaan audit. Hasil yang diperoleh adalah faktor ukuran perusahaan, profitabilitas, Internal Auditor dan opini auditor mempunyai pengaruh yang signifikan terhadap rentang waktu penyelesaian pelaksanaan audit laporan keuangan tahunan. Sedangkan jenis industri dan reputasi auditor tidak mempunyai pengaruh yang signifikan terhadap rentang waktu penyelesaian pelaksanaan audit laporan keuangan tahunan.

Dari uraian diatas maka hipotesa yang diajukan adalah:

\section{Ha1: Terdapat pengaruh faktor internal (solvabilitas, Internal Auditor dan size perusahaan) terhadap Audit Delay dan Timeliness}

Penelitian empiris yang dapat menunjukkan faktor-faktor yang berhubungan dengan perilaku ketepatwaktuan laporan keuangan dilakukan oleh Dyer \& Mc Hugh (1975) yang meneliti faktor faktor spesifik perusahaan, yaitu ukuran perusahaan, tanggal akhir tahun tutup buku dan tingkat profitabilitas. Temuan mereka menghasilkan adanya hubungan yang signifikan dari ukuran perusahaan dan tanggal akhir tahun tutup buku dengan ketepatwaktuan laporan keuangan, sementara tingkat profitabilitas tidak berhubungan signifikan dengan ketepatwaktuan laporan keuangan. Dalam penelitian Whittered (1980) dan Owusu-Ansah (2000) menemukan bahwa tidak ada pendekatan yang memadai untuk menjelaskan perilaku pelaporan keuangan dari perusahaan.

Sementara itu Givoly \& Palmon (1982) menggunakan ukuran perusahaan dan kompleksitas operasi untuk dapat menjelaskan ketepatwaktuan (Timeliness), menemukan bahwa penundaan pelaporan erat kaitannya dengan pola industri dan tradisi kabar buruk (bad news), cenderung menyebabkan keterlambatan pengumuman dan ukuran perusahaan menunjukkan hubungan negatif dengan ketepatwaktuan laporan keuangan tahunan. 
Penelitian yang dilakukan Givoly \& Palmon (1982) juga menguji pengaruh karakteristik perusahaan dengan ketepatwaktuan. Hasil penelitian menunjukkan bahwa ukuran perusahaan berhubungan negatif dengan keterlambatan pelaporan dan kompleksitas audit secara langsung berhubungan dengan keterlambatan pelaporan keuangan perusahaan.

Penelitian yang dilakukan oleh Chambers \& Pennman (1984) di Amerika menemukan bukti empiris bahwa ada hubungan terbalik antara besarnya perusahaan dan keterlambatan pelaporan.

Dari uraian diatas maka hipotesa yang diajukan adalah :

\section{Ha2: Terdapat Pengaruh Faktor Eksternal (Ukuran KAP) terhadap Audit Delay dan Timeliness.}

Penelitian empiris yang dapat menunjukkan faktor kemampuan perusahaan dalam menghasilkan laba selama periode tertentu adalah Rasio Profitabilitas, dari hal ini dapat pula memberikan gambaran tentang tingkat efektifitas manajemen dalam melaksanakan kegiatan operasinya, namun tingkat profitabilitas masih dipengaruh faktor internal perusahaan yang lain, misalnya dari faktor solvabilitas, pengaruh Internal Auditor dan pengaruh size perusahaan. Dengan model hubungan seperti ini, maka hipotesa yang diajukan adalah :

\section{Ha3 : Terdapat pengaruh Internal (Solvabilitas, Internal Auditor dan Size Perusahaan) yang dimoderasi Profitabilitas terhadap Audit Delay dan Timeliness}

\section{METODE PENELITIAN}

Jenis penelitian yang digunakan adalah data kuantitatif, yaitu data yang berisi angka dan perhitingan sistematis. Sedangkan berdasarkan sumber data termasuk data sekunder yang diperoleh dari pihak kedua. Dalam penelitian ini adalah Bursa Efek Indonesia. Penelitian ini mengambil populasi perusahaan Consumer Goods yang terdaftar di BEI dengan mengambil sampel perusahaan tahun 2013 sampai dengan tahun 2017. Pemilihan sampel dilakukan dengan "purposive sampling" dengan kriteria pertama, Perusahaan yang digunakan dalam penelitian ini adalah perusahaan yang masuk kategori industri Consumer Goods. Kedua, Perusahaan yang tetap aktif menerbitkan laporan keuanganya dan masih tetap beroperasi serta tidak menghentikan aktivitasnya di pasar modal sampai dengan bulan Desember 2017. Ketiga, Perusahaan yang memeroleh laba positif. Terdapat 24 perusahaan yang memenuhi kereteria dengan total sample sebanyak 72 


\section{HASIL DAN PEMBAHASAN}

Analisis statistik deskriptif memberikan gambaran umum mengenai varabel independen terhadap variabel dependen, meliputi variabel solvabilitas, Internal Auditor, ukuran perusahaan, Ukuran KAP, dan profitabilitas terhadap Audit Delay dan Timeliness. Gambaran umum variabel independen terhadap variabel dependen dapat dilihat dari rata-rata (mean), nilai minimum dan maximum, dan standar deviasi. Hasil statistik deskriptif untuk masingmasing variabel terdapat pada tabel berikut :

Tabel 5. 1

\section{Hasil Uji Statistik Deskriptif}

\begin{tabular}{|c|c|c|c|c|c|}
\hline & $\mathrm{N}$ & Minimum & Maximum & Mean & Std. Deviation \\
\hline DER & 50 & , 17 & 1,72 &, 8700 &, 42289 \\
\hline IA & 50 & ,00 & 1,00 & ,9800 & 14142 \\
\hline KAP & 50 &, 00 & 1,00 &, 5000 &, 50508 \\
\hline SIZE & 50 & 5,11 & 12,99 & 7,0594 & 1,67969 \\
\hline ROA & 50 & 1,59 & 30,50 & 9,9854 & 6,23641 \\
\hline AUD & 50 & 48,00 & 157,00 & 83,0200 & 18,00396 \\
\hline TIME & 50 & 10,00 & 18,00 & 15,2000 & 1,62882 \\
\hline
\end{tabular}

Berdasarkan tabel 5.3 di atas dapat diketahui bahwa jumlah observasi dalam penelitian $(\mathrm{N})$ adalah 50 dan jumlah variabelnya adalah 7 dengan rincian 2 variabel dependen yaitu Audit Delay dan Timeliness dan 5 variabel independen yaitu solvabilitas (DER), Internal Auditor (IA), Ukuran Perusahaan (Size), Ukuran KAP, Profitabilitas (ROE). Pada variabel DER hasil yang didapat menunjukkan bahawa, nilai minimum sebesar 0,17. Sedangkan nilai tertingginya sebesar 1,72. Angka rata-rata adalah sebesar 0,8700. Menujukkan bahwa rata-rata presentase perusahaan barang konsumsi sebesar $87 \%$.

Pada variabel Internal Auditor (IA) hasil yang didapat menunjukkan bahwa, nilai minimum sebesar ,00, Sedangkan nilai tertingginya sebesar 1,00, angka rata-rata adalah sebesar 0,00 , menujukkan bahwa rata-rata nilai presentase total IA sebesar $1 \%$. Pada variabel Ukuran Perusahaan (SIZE) hasil yang didapat menunjukkan bahwa, nilai minimum sebesar 5,11, Sedangkan nilai tertingginya sebesar 12,99, Angka rata-rata adalah sebesar 7,0594, menujukkan bahwa rata-rata nilai presentase total Ukuran Perusahaan sebesar $70 \%$.

Pada variabel Ukuran Kantor Akuntan Publik (KAP) hasil yang didapat menunjukkan bahwa, nilai minimum sebesar 0,00, Sedangkan nilai tertingginya sebesar 1,00, Angka rata- 


\section{P ISSN 2622-7177 \\ [ACCOUNTING GLOBAL JOURNAL] E ISSN 2623-1778}

rata adalah sebesar 1,00, menujukkan bahwa rata-rata nilai presentase total Profitabilitas sebesar 1\%. Pada variabel Profitabilitas (ROA) hasil yang didapat menunjukkan bahwa, nilai minimum ROA sebesar 1,59, Sedangkan nilai tertingginya sebesar 30,5, Angka rata-rata adalah sebesar 9,9854, menujukkan bahwa rata-rata nilai presentase total Profitabilitas sebesar $99 \%$.

Pada variabel Audit Delay (AUD) hasil yang didapat menunjukkan bahwa, nilai minimum AUD sebesar 48,00, Sedangkan nilai tertingginya sebesar 157,00, Angka rata-rata adalah sebesar 83,0200, menujukkan bahwa rata-rata nilai presentase $83 \%$. Pada variabel Timeliness hasil yang didapat menunjukkan bahwa, nilai minimum sebesar 10,00, Sedangkan nilai tertingginya sebesar 18,00, Angka rata-rata adalah sebesar 15,20 menujukkan bahwa rata-rata nilai presentase $15 \%$.

\section{Uji Normalitas}

Uji normalitas digunakan untuk menguji data bahwa distribusinya normal atau tidak, data dari variabel dependen dan variabel independen. Normal atau tidaknya suatu data dapat dilihat dari grafik normal probability plot. Dalam grafik itu akan menunjukkan penyebaran plot dengan asumsi- asumsi sebagai berikut:

1. Jika penyebaran data berada disekitar garis diagonal atau berada di sekitar $45^{\circ}$, maka diasumsikan model regresi memenuhi uji normalitas.

2. Jika penyebaran data berada jauh disekitar garis diagonal atau tidak berada di sekitar $45^{\circ}$, maka diasumsikan model regresi tidak memenuhi uji normalitas.

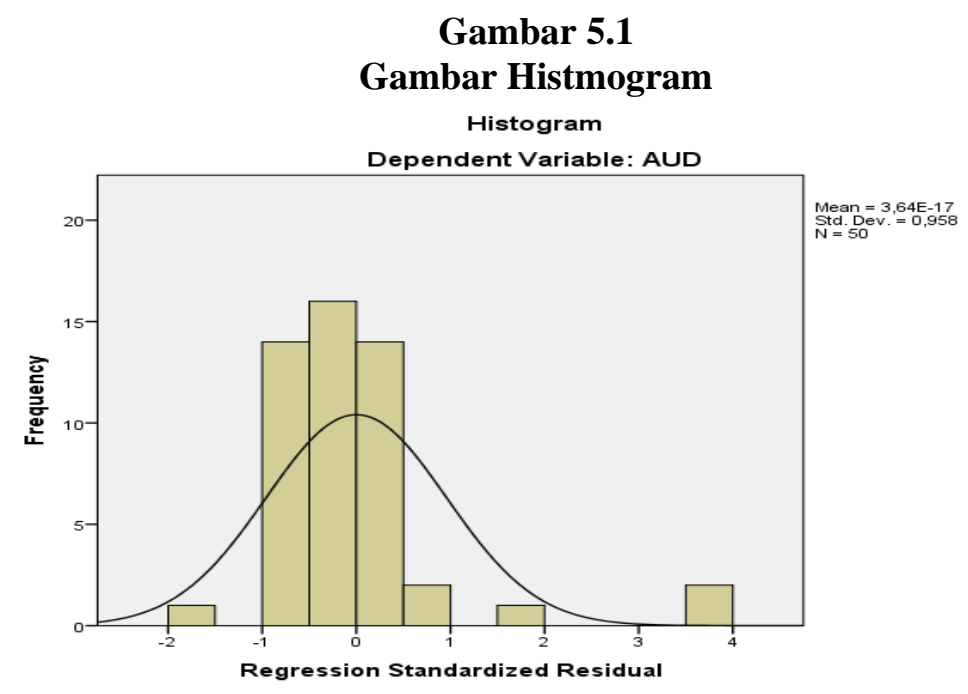




\section{P ISSN 2622-7177 \\ [ACCOUNTING GLOBAL JOURNAL] E ISSN 2623-1778}

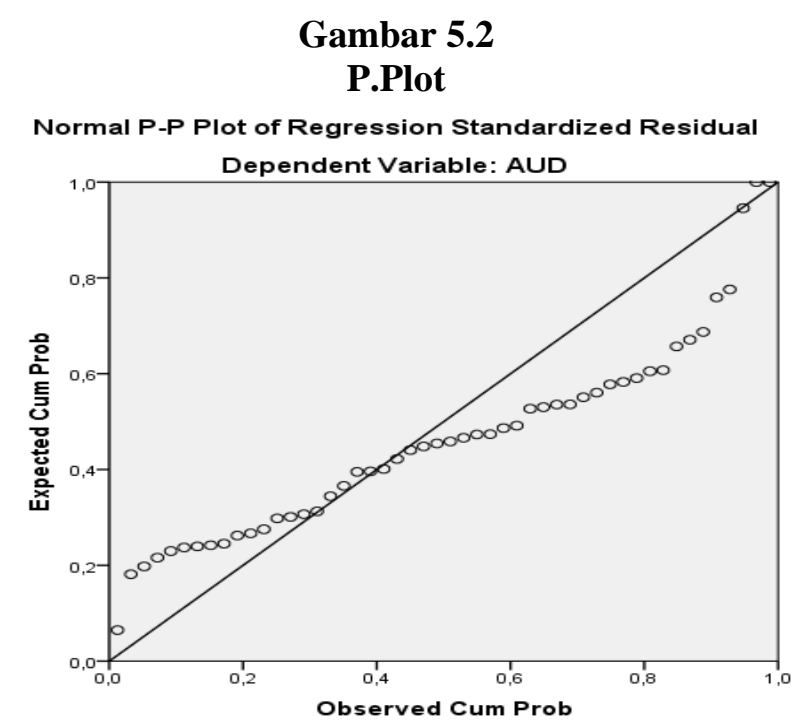

Tabel 5.4

Hasil Uji Normalitas

One-Sample Kolmogorov-Smirnov Test

\begin{tabular}{llr} 
& & \multicolumn{2}{c}{ Unstandardized } \\
& & 50 \\
$\mathrm{~N}$ & Mean &, 0757890 \\
Normal Parameters & a,b & 19711023 \\
& Std. Deviation &, 185 \\
& Absolute &, 185 \\
Most Extreme Differences Positive &,- 143 \\
& Negative & 1,307 \\
Kolmogorov-Smirnov Z & &, 066 \\
\hline Asymp. Sig. (2-tailed) & &
\end{tabular}

a. Test distribution is Normal.

b. Calculated from data.

Berdasarkan tabel di atas, dapat diketahui nilai signifikansinya sebesar 0,066 yang berarti lebih besar dari 0,05, maka dapat disimpulkan data berdistribusi normal. Selain menggunakan perhitungan statistik, normalitas data dapat dilihat dengan gambar P-P Plot Normalitas. Dengan metode ini data dapat dikatakan berdistribusi normal apabila data menyebar di sekitar garis diagonal dan mengikuti arah garis diagonal dari grafik normal P-Plot Of Regression. Hal ini dapat dilihat pada gambar terlihat titik-titik menyebar di sekitar garis diagonal, serta penyebarannya mengikuti arah garis diagonal. Maka model regresi layak dipakai karena telah memenuhi asumsi normalitas.

\section{Uji Multikolinieritas}

Uji multikolinieritas digunakan untuk mengetahui ada tidaknya multikolinieritas dengan menyelidiki besarnya interkolerasi antar variabel bebasnya. Ada tidaknya multikolinieritas 


\section{[ACCOUNTING GLOBAL JOURNAL]

dapat dilihat dari nilai Tolerance dan Variance Inflation Factor (VIF). Jika nilai Tolerance $\geq$ 0,10 dan nilai VIF $\leq 10$ maka tidak terjadi multikolinieritas. Hasil uji multikolinieritas dapat dilihat pada tabel berikut:

Tabel 5.2

Hasil Uji Multikolinieritas

\begin{tabular}{llll}
\hline \multirow{2}{*}{ Model } & & \multicolumn{2}{c}{ Collinearity Statistics } \\
& & Tolerance & VIF \\
\hline \multirow{4}{*}{1} & (Constant) & & \\
& Ln_DER &, 301 & 3,318 \\
& Ln_SIZE &, 937 & 1,067 \\
& Ln_ROA &, 312 & 3,200 \\
\hline
\end{tabular}

Berdasarkan tabel di atas menunjukkan semua variabel bebas mempunyai nilai Tolerance $\geq$ 0,10 dan nilai $\mathrm{VIF} \leq 10$. Dengan demikian, dapat disimpulkan bahwa seluruh variabel bebas dalam penelitian ini tidak terjadi multikolinieritas.

\section{Uji Heteroskedastisitas}

Uji heteroskedastisitas digunakan untuk menguji apakah dalam regresi terjadi ketidaksamaan variance dari residual satu pengamatan ke pengamatan lain, dengan meregresi nilai absolut residual terhadap variabel independen. Uji ini terlihat dari probabilitas signifikansinya di atas 0,05 (> 0,05) berati tidak mengandung adanya heteroskedastisitas (Ghozali, 2011). Hasil uji heteroskedastisitas dapat dilihat pada tabel berikut ini:

Tabel 5.3

Hasil Uji Heteroskedastisitas

\begin{tabular}{|c|c|c|c|c|c|}
\hline \multicolumn{6}{|l|}{ Coefficients $^{\mathrm{a}}$} \\
\hline \multirow[b]{2}{*}{ Model } & \multicolumn{2}{|c|}{ Unstandardized Coefficients } & \multirow{2}{*}{$\begin{array}{l}\text { Standardized } \\
\text { Coefficients } \\
\text { Beta }\end{array}$} & \multirow{2}{*}{$\mathrm{t}$} & \multirow{2}{*}{ Sig. } \\
\hline & B & Std. Error & & & \\
\hline (Constant) & $4,086 \mathrm{E}-016$ & ,306 & & 000 & 1,000 \\
\hline \multirow[t]{3}{*}{ Ln DER } & ,000 & ,070 & ,000 &, 000 & 1,000 \\
\hline & ,000 & 146 & ,000 & ,000 & 1,000 \\
\hline & 000 & 069 & 000 & 000 & 1,000 \\
\hline
\end{tabular}

Berdasarkan tabel di atas menunjukkan bahwa semua variabel bebas mempunyai nilai probabilitas signifikansi lebih besar dari 0,05. Dengan demikian, kesimpulannya bahwa tidak terjadi heteroskedastisitas dalam model regresi. Deteksi ada tidaknya heteroskedastisitas juga dapat dilakukan dengan melihat ada tidaknya pola tertentu pada grafik scatterplot antara SRESID dengan ZPRED. Hasil pengujian heteroskedastisitas dapat dilihat pada gambar berikut ini: 


\section{Gambar 5.3}

Hasil Scatterplot Uji Heteroskedastisitas

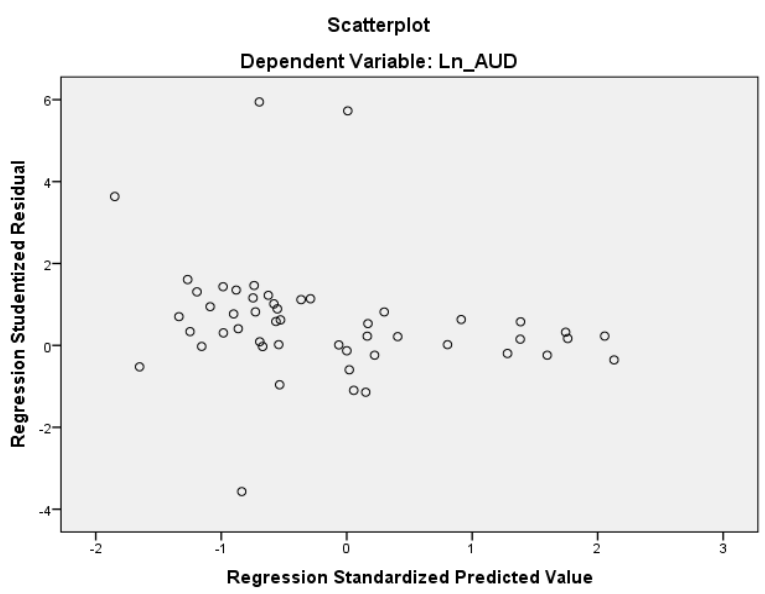

Dari grafik scatterplot dapat dilihat bahwa tidak adanya pola yang jelas, serta titik-titik menyebar di atas dan di bawah angka 0 maka tidak terjadi heteroskedastisitas.

\section{Uji Autokorelasi}

Uji autokorelasi digunakan untuk menguji apakah dalam model regresi linier ada korelasi antara residual periode $\mathrm{t}$ dengan residual pada periode $\mathrm{t}-1$ (periode sebelumnya). Jika terjadi korelasi, maka ada masalah autokorelasi. Autokorelasi terjadi karena observasi yang berurutan sepanjang waktu berkaitan satu sama lain (Ghozali, 2011). Untuk melihat adanya autokorelasi menggunakan tabel Durbin Watson Test (DW). Hasil uji autokorelasi dapat dilihat pada tabel dibawah ini :

Tabel 5.6

Hasil Uji Autokorelasi

Model Summary ${ }^{b}$

\begin{tabular}{llllll}
\hline Model & R & R Square & $\begin{array}{l}\text { Adjusted R } \\
\text { Square }\end{array}$ & $\begin{array}{l}\text { Std. Error } \\
\text { of the } \\
\text { Estimate }\end{array}$ & $\begin{array}{l}\text { Durbin- } \\
\text { Watson }\end{array}$ \\
\hline 1 &, $000 \mathrm{a}$ &, 000 &,- 143 &, 11972698 & 2,190 \\
\hline
\end{tabular}

a. Hasil uji autokorelasi pada tabel menunjukkan nilai Durbin Watson (DW) adalah 2,190. Adapun nilai Durbin-Watson tabel untuk $\mathrm{n}=50$ dan $\mathrm{k}=5$ pada tingkat signifikan $5 \%$ didapatkan nilai sebesar 1,5683 dan nilai sebesar 1,7799. Hasil pengujian yang dapat dilihat pada nilai DW sebesar 2,208 yang berarti terletak diantara $\mathrm{dU}<\mathrm{d}<4-\mathrm{dU}(1,7799<2,208<$ 2,2201). Hal ini berarti model regresi di atas tidak terdapat masalah autokorelasi. 


\section{P ISSN 2622-7177 \\ [ACCOUNTING GLOBAL JOURNAL] E ISSN 2623-1778}

\subsubsection{Regresi Linier Berganda}

Tabel 5.7

Coefficients $^{\mathrm{a}}$

\section{Hasil Analisis Regresi Linier Berganda}

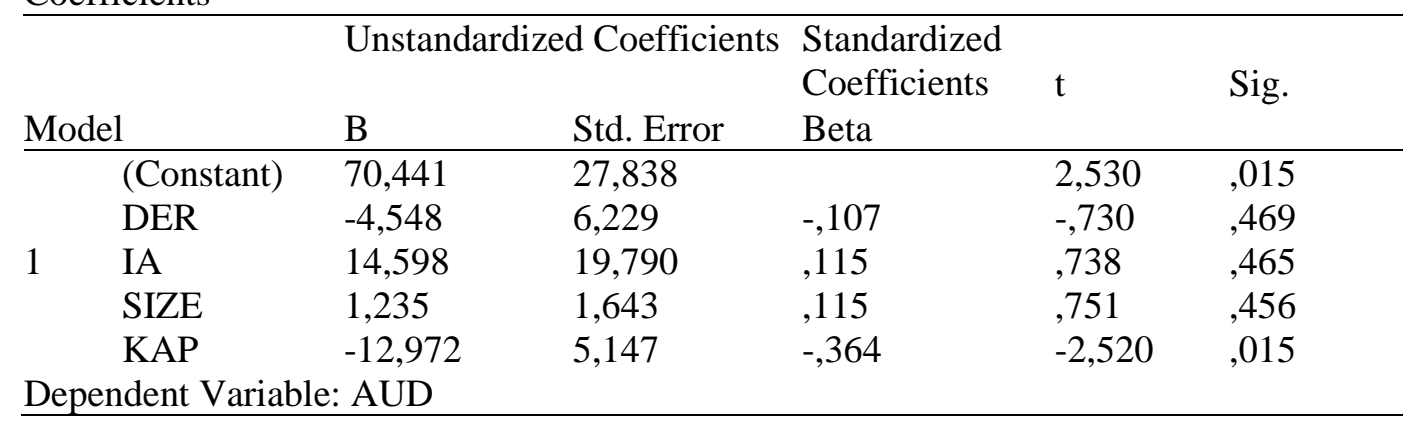

a. Uji regresi berganda untuk Audit Delay sebagai berikut :

Berdasarkan tabel diperoleh persamaan regresi sebagai berikut :

$\mathrm{Y}=\mathrm{a}+\mathrm{b} \times 1+\mathrm{b} \times 2+\mathrm{b} \times 3+\mathrm{b} \times 4+\mathrm{b} \times 5+e$

$\mathrm{Y}=70,44-4,548 \mathrm{X} 1+14,59 \mathrm{X} 2+1,23 \mathrm{X} 3-12,97 \mathrm{X} 4+\mathrm{e}$

Penjabaran dari persamaan regresi berganda diatas, sebagai berikut :

Konstanta sebesar 70,441, artinya apabila Solvabilitas, Internal Auditor, Ukuran Perusahaan, KAP nilainya diasumsikan tetap, maka Audit Delay (Y) adalah sebesar 70,441.

1. Koefisien regresi variabel Solvabilitas $(\mathrm{DER})=-4,548$, nilai itu menunjukkan pengaruh negatif terhadap Audit Delay dengan koefisien regresi sebesar -4,548 yang artinya jika solvabilitas mengalami peningkatan sebesar 1 satuan, maka Audit Delay akan mengalami penurunan sebesar 4,548 dengan asumsi variabel independen lainnya tetap.

2. Koefisien regresi variabel Internal Auditor $(\mathrm{AI})=14,598$, nilai itu menunjukkan pengaruh positif terhadap Audit Delay dengan koefisien regresi sebesar 14,598, yang artinya jika Internal Auditor (AI) mengalami peningkatan sebesar 1 satuan, maka Audit Delay akan mengalami peningkatan sebesar 14,598 dengan asumsi variabel independen lainnya tetap.

3. Koefisien regresi variabel Ukuran Perusahaan $(\mathrm{SIZE})=1,235$ nilai itu menunjukkan pengaruh positif terhadap Audit Delay dengan koefisien regresi sebesar 1,235 yang artinya jika Ukuran Perusahaan (SIZE) mengalami peningkatan sebesar 1 satuan, maka 


\section{[ACCOUNTING GLOBAL JOURNAL]

Audit Delay akan mengalami peningkatan sebesar 1,235 dengan asumsi variabel independen lainnya tetap.

4. Koefisien regresi variabel Ukuran Kantor Akuntan Publik (KAP) $=-12,972$ nilai itu menunjukkan pengaruh negatif terhadap Audit Delay dengan koefisien regresi sebesar 12,972 yang artinya jika Ukuran Kantor Akuntan Publik (KAP) mengalami peningkatan sebesar 1 satuan, maka Audit Delay akan mengalami penurunan sebesar 12,972dengan asumsi variabel independen lainnya tetap.

5. Standart error (e) menunjukkan tingkat kesalahan pengganggu.

\section{Tabel 5.8}

Hasil Analisis Regresi Linier Berganda Coefficients $^{\mathrm{a}}$

\begin{tabular}{|c|c|c|c|c|c|c|}
\hline \multirow[b]{2}{*}{ Model } & & \multicolumn{2}{|c|}{ Unstandardized Coefficients } & \multicolumn{2}{|l|}{ Standardized } & \multirow{2}{*}{ Sig. } \\
\hline & & B & Std. Error & Beta & & \\
\hline \multirow{5}{*}{1} & (Constant) & 14,152 & 2,689 & & 5,262 & ,000 \\
\hline & DER & 257 & 602 & ,067 & ,428 & 671 \\
\hline & IA &,- 063 & 1,912 &,- 005 &,- 033 & ,974 \\
\hline & SIZE & 134 &, 159 &, 138 & 845 & ,403 \\
\hline & KAP &,- 124 & 497 &,- 038 &,- 248 &, 805 \\
\hline
\end{tabular}

Dependent Variable: TIME

Sumber : data sekunder diolah, 2019

b. Uji regresi berganda untuk Timeliness sebagai berikut :

Berdasarkan tabel diperoleh persamaan regresi sebagai berikut :

$\mathrm{Y}=\mathrm{a}+\mathrm{b} \times 1+\mathrm{b} \times 2+\mathrm{b} \times 3+\mathrm{b} \times 4+\mathrm{b} \times 5+e$

$\mathrm{Y}=14,152+0,257 \mathrm{X} 1-0,063 \mathrm{X} 2+0,134 \mathrm{X} 3-0,124 \mathrm{X} 4+\mathrm{e}$

Penjabaran dari persamaan regresi berganda diatas, sebagai berikut :

Konstanta sebesar 14,152 artinya apabila Solvabilitas, Internal Auditor, Ukuran Perusahaan, KAP nilainya diasumsikan tetap, maka Timeliness (Y) adalah sebesar 14,152.

1. Koefisien regresi variabel Solvabilitas $(\mathrm{DER})=-4,548$, nilai itu menunjukkan pengaruh negatif terhadap Audit Delay dengan koefisien regresi sebesar -4,548 yang artinya jika solvabilitas mengalami peningkatan sebesar 1 satuan, maka Audit Delay akan mengalami penurunan sebesar 4,548 dengan asumsi variabel independen lainnya tetap. 


\section{[ACCOUNTING GLOBAL JOURNAL]

2. Koefisien regresi variabel Internal Auditor $(\mathrm{AI})=14,598$, nilai itu menunjukkan pengaruh positif terhadap Audit Delay dengan koefisien regresi sebesar 14,598, yang artinya jika Internal Auditor (AI) mengalami peningkatan sebesar 1 satuan, maka Audit Delay akan mengalami peningkatan sebesar 14,598 dengan asumsi variabel independen lainnya tetap.

3. Koefisien regresi variabel Ukuran Perusahaan $(\mathrm{SIZE})=1,235$ nilai itu menunjukkan pengaruh positif terhadap Audit Delay dengan koefisien regresi sebesar 1,235 yang artinya jika Ukuran Perusahaan (SIZE) mengalami peningkatan sebesar 1 satuan, maka Audit Delay akan mengalami peningkatan sebesar 1,235 dengan asumsi variabel independen lainnya tetap.

4. Koefisien regresi variabel Ukuran Kantor Akuntan Publik (KAP) $=-12,972$ nilai itu menunjukkan pengaruh negatif terhadap Audit Delay dengan koefisien regresi sebesar 12,972 yang artinya jika Ukuran Kantor Akuntan Publik (KAP) mengalami peningkatan sebesar 1 satuan, maka Audit Delay akan mengalami penurunan sebesar 12,972dengan asumsi variabel independen lainnya tetap.

5. Standart error (e) menunjukkan tingkat kesalahan pengganggu.

\section{Uji Hipotesis}

\section{Uji t}

Pengujian ini dilakukan untuk mengetahui apakah masing-masing variabel independen mempengaruhi variabel dependen secara signifikan. Adapun hasil pengujiannya adalah sebagai berikut:

Tabel 5.9

Uji t

Coefficients $^{\mathrm{a}}$

\begin{tabular}{|c|c|c|c|c|c|c|}
\hline \multirow{2}{*}{\multicolumn{2}{|c|}{ Model }} & \multicolumn{2}{|c|}{ Unstandardized Coefficients } & \multirow{2}{*}{$\begin{array}{l}\text { Standardized } \\
\text { Coefficients } \\
\text { Beta }\end{array}$} & \multirow{2}{*}{$\mathrm{t}$} & \multirow{2}{*}{ Sig. } \\
\hline & & B & Std. Error & & & \\
\hline \multirow{5}{*}{1} & (Constant) & 70,441 & 27,838 & & 2,530 & 015 \\
\hline & DER & $-4,548$ & 6,229 &,- 107 &,- 730 & ,469 \\
\hline & IA & 14,598 & 19,790 & ,115 & ,738 & ,465 \\
\hline & SIZE & 1,235 & 1,643 & ,115 &, 751 & , 456 \\
\hline & KAP & $-12,972$ & 5,147 &,- 364 & $-2,520$ & 015 \\
\hline
\end{tabular}


Uji statistik $\mathrm{t}$ digunakan untuk mengukur pengaruh satu variabel independen secara individual terhadap variabel dependen. Untuk mengetahui hasil uji parsial, dapat dilihat dari nilai signifikansinya dan membandingkan dengan nilai signifikansi yang telah ditetapkan, yaitu sebesar 0,05. Jika nilai signifikan lebih kecil dari 0,05 atau 5\% maka dapat dinyatakan bahwa hipotesis diterima dan dapat dikatakan berpengaruh. Tetapi jika nilai signifikan lebih besar dari 0,05 atau 5\% maka dapat dinyatakan bahwa hipotesis ditolak dan dapat dikatakan tidak berpengaruh.

\section{Terdapat pengaruh Internal dari Solvabilitas (DER) terhadap Audit Delay}

Hipotesis (Ha.1) dalam penelitian ini bahwa ada pengaruh internal untuk Solvabilitas (DER) terhadap Audit Delay. Berdasarkan hasil uji statistik nilai t hitung sebesar $0,730<1,67591$ dengan nilai sig 0,469. Nilai sig tersebut lebih besar dari 0,05 maka nilai tersebut tidak signifikan. Hal ini berarti variabel Solvabilitas berpengaruh negatif dan tidak signifikan terhadap Audit Delay, berarti Ha.1 ditolak.

\section{Terdapat pengaruh Internal dari Internal Auditor (IA) terhadap Audit Delay}

Hipotesis (Ha.1) berikutnya dalam penelitian ini adalah pengaruh Internal Auditor terhadap Audit Delay. Berdasarkan hasil uji statistik nilai t hitung sebesar 0, 738 dengan nilai sig 0,465 . Nilai sig tersebut lebih besar dari 0,05 maka nilai tersebut tidak signifikan, dan dari uji $\mathrm{t}$ dapat dilihat dari nilai $\mathrm{t}$ hitung lebih kecil nilai $\mathrm{t}$ tabel $0,483<1,67591$. Hal ini berarti variabel Internal Auditor tidak berpengaruh terhadap Audit Delay, berarti Ha.1 ditolak.

\section{Terdapat pengaruh Internal dari Ukuran Perusahaan terhadap Audit Delay}

Hipotesis (Ha.1) dalam penelitian ini adalah ada pengaruh Size Perusahaan terhadap Audit Delay. Berdasarkan hasil uji statistik nilai t hitung sebesar 0,751dengan nilai sig 0,456. Nilai sig tersebut lebih besar dari 0,05 maka nilai tersebut tidak signifikan, dan dari uji $\mathrm{t}$ dapat dilihat dari nilai t hitung lebih kecil nilai t tabel $0,751<1,67591$. Hal ini berarti variabel Size Perusahaan tidak signifikan terhadap Audit Delay, berarti Ha.1 untuk size perusahaan ditolak.

\section{Terdapat pengaruh Eksternal dari Ukuran KAP terhadap Audit Delay}

Hipotesis (Ha.2) dalam penelitian ini adalah ada pengaruh ukuran KAP terhadap Audit Delay. Berdasarkan hasil uji statistik nilai t hitung negatif sebesar -2,520 dengan nilai sig 0,015. Nilai sig tersebut lebih kecil dari 0,05 maka nilai tersebut signifikan, dan dari 
uji $t$ dapat dilihat dari nilai $t$ hitung lebih kecil nilai $t$ tabel $-2,520<1,67591$. Hal ini berarti variabel ukuran KAP signifikan terhadap Audit Delay, berarti Ha.2 untuk ukuran KAP diterima.

Tabel 5.10

Uji t

Coefficients $^{\mathrm{a}}$

\begin{tabular}{|c|c|c|c|c|c|c|}
\hline \multirow[b]{2}{*}{ Model } & & \multicolumn{2}{|c|}{ Unstandardized Coefficients } & \multicolumn{2}{|l|}{ Standardized } & \multirow{2}{*}{ Sig. } \\
\hline & & B & Std. Error & Beta & & \\
\hline \multirow{5}{*}{1} & (Constant) & 14,152 & 2,689 & & 5,262 & ,000 \\
\hline & DER & ,257 & ,602 & ,067 & ,428 & 671 \\
\hline & IA &,- 063 & 1,912 &,- 005 &,- 033 & 974 \\
\hline & SIZE & 134 & 159 & 138 &, 845 & ,403 \\
\hline & KAP &,- 124 & ,497 &,- 038 &,- 248 &, 805 \\
\hline
\end{tabular}

\section{Terdapat pengaruh Internal dari Solvabilitas (DER) terhadap Timeliness}

Hipotesis pertama (Ha1) dalam penelitian ini bahwa ada pengaruh internal Solvabilitas (DER) terhadap Timeliness. Berdasarkan hasil uji statistik nilai t hitung sebesar 0,428 dengan nilai sig 0,671 Nilai sig tersebut lebih besar dari 0,05 maka nilai tersebut tidak signifikan. Hal ini berarti variabel Solvabilitas tidak berpengaruh terhadap Timeliness, berarti Ha1 ditolak.

\section{Terdapat pengaruh Internal dari Internal Auditor terhadap Timeliness}

Hipotesis berikut dalam penelitian ini adalah ada pengaruh Internal Auditor terhadap Timeliness. Berdasarkan hasil uji statistik nilai t hitung sebesar -0,033dengan nilai sig 0,974. Nilai sig tersebut lebih besar dari 0,05 maka nilai tersebut tidak signifikan, dan dari uji t dapat dilihat dari nilai t hitung lebih kecil nilai t tabel $-0,033<1,67591$. Hal ini berarti variabel Internal Auditor tidak berpengaruh terhadap Timeliness, berarti Ha.1 ditolak.

\section{Terdapat pengaruh Internal dari Size Perusahaan terhadap Timeliness}

Hipotesis berikut dalam penelitian ini adalah ada pengaruh Size Perusahaan terhadap Timeliness. Berdasarkan hasil uji statistik nilai t hitung sebesar 0,845 dengan nilai sig 0,403. Nilai sig tersebut lebih besar dari 0,05 maka nilai tersebut tidak signifikan, dari uji $t$ dapat dilihat dari nilai $t$ hitung lebih kecil nilai $t$ tabel $-0,845<1,67591$. Hal ini berarti variabel Size Perusahaan tidak signifikan terhadap Audit Delay, berarti Ha.1 ditolak. 


\section{Terdapat pengaruh Eksternal dari Ukuran KAP terhadap Timeliness}

Hipotesis berikut dalam penelitian ini adalah dari faktor eksternal Ukuran KAP berpengaruh terhadap Timeliness. Berdasarkan hasil uji statistik diatas nilai nilai $\mathrm{t}$ hitung sebesar -,248< dari nilai t tabel sebesar 1,675 dengan nilai signifikan 0,805 lebih besar dari 0,05 artinya bahwa pengaruh eksternal dari Ukuran KAP tidak berpengaruh terhadap Timeliness pada perusahaan consumer goods yang terdaftar di BEI tahun 2013-2017. Sehingga hipotesis (Ha.2) yang mengatakan bahwa faktor eksternal dari Ukuran KAP berpengaruh terhadap Timeliness ditolak.

\section{Terdapat Pengaruh Faktor Internal yang dimoderasi Profitabilitas terhadap Audit Delay}

Pengujian ini dilakukan untuk mengetahui apakah masing-masing variabel independen yang ada pada faktor internal mempengaruhi variabel Audit Delay yang dimoderasi variabel Profitabilitas secara signifikan. Adapun hasil pengujiannya adalah sebagai berikut:

\section{a. Pengaruh Faktor Internal yang dimoderasi Profitabilitas terhadap Audit Delay}

Tabel 5.11

Model Summary

\begin{tabular}{lllll}
\hline Model & $\mathrm{R}$ & R Square & $\begin{array}{l}\text { Adjusted R } \\
\text { Square }\end{array}$ & $\begin{array}{l}\text { Std. Error of the } \\
\text { Estimate }\end{array}$ \\
\hline 1 &, $387^{\mathrm{a}}$ &, 149 &, 074 & 17,32646 \\
\hline
\end{tabular}

Model Summary

\begin{tabular}{lrrrr}
\hline Model & R & R Square & $\begin{array}{c}\text { Adjusted R } \\
\text { Square }\end{array}$ & $\begin{array}{l}\text { Std. Error of } \\
\text { the Estimate }\end{array}$ \\
\hline 1 &, $239^{\mathrm{a}}$ &, 057 &,- 027 & 18,24297
\end{tabular}

Berdasarkan hasil uji statistik nilai R2 yang pertama sebesar 0,149 atau 14,9\%, setelah ada persamaan regresi kedua nilai R2 turun menjadi 0,057 atau 5,7\%. Dengan melihat hasil diatas maka dapat disimpulkan bahwa Profitabilitas bukan sebagai variabel moderating, artinya bahwa Profitabilitas tidak memoderasi hubungan antara DER, Internal Auditor dan Ukuran Perusahaan dengan Audit Delay, sehingga hipotesis Ha.3 yang mengatakan bahwa faktor internal DER Internal Auditor dan Ukuran Perusahaan berpengaruh terhadap Audit Delay yang dimoderasi oleh Profitabilitas ditolak. 


\section{b. Pengaruh Faktor Internal yang dimoderasi Profitabilitas terhadap Timeliness}

Tabel 5.12

Model Summary

\begin{tabular}{|c|c|c|c|c|}
\hline Model & $\mathrm{R}$ & R Square & $\begin{array}{l}\text { Adjusted R } \\
\text { Square }\end{array}$ & $\begin{array}{l}\text { Std. Error of the } \\
\text { Estimate }\end{array}$ \\
\hline 1 &, $174^{\mathrm{a}}$ & ,030 &,- 056 & 1,67380 \\
\hline \multicolumn{5}{|c|}{$\begin{array}{c}\text { a. Predictors: (Constant), KAP, SIZE, DER, IA } \\
\text { Model Summary }\end{array}$} \\
\hline Model & $\mathrm{R}$ & R Square & $\begin{array}{l}\text { Adjusted R } \\
\text { Square }\end{array}$ & $\begin{array}{l}\text { Std. Error of the } \\
\text { Estimate }\end{array}$ \\
\hline 1 &, $170^{\mathrm{a}}$ & ,029 &,- 057 & 1,67490 \\
\hline
\end{tabular}

a. Predictors: (Constant), MTime, IA, SIZE, DER

Berdasarkan hasil uji statistik nilai R2 yang pertama sebesar 0,30 atau 3\%, setelah ada persamaan regresi kedua nilai R2 turun menjadi 0,029 atau 2,9\%. Dengan melihat hasil diatas maka dapat disimpulkan bahwa Profitabilitas bukan sebagai variabel moderating.

Artinya bahwa Profitabilitas tidak memoderasi hubungan antara DER, Internal Auditor dan Ukuran Perusahaan dengan Timeliness, sehingga hipotesis Ha.3 yang mengatakan bahwa faktor internal DER Internal Auditor dan Ukuran Perusahaan berpengaruh terhadap Timeliness yang dimoderasi oleh Profitabilitas ditolak.

\section{Pengaruh Faktor Internal Solvabilitas Terhadap Audit Delay}

Berdasarkan hasil uji Hipotesis pengaruh Solvabilitas terhadap Audit Delay bahwa Solvabilitas tidak berpengaruh terhadap Audit Delay, hal ini ditunjukkan dengan nilai signifikan $0.469>0,05$ Artinya bahwa tingkat solvabilitas yang diukur dengan DER tidak dapat mempengaruhi Audit Delay.

Hasil penelitian ini menujukkan tidak adanya pengaruh tingginya tingkat solvabilitas perusahaan akan mengakibatkan waktu penyelesaian audit semakin lama. Hal ini dapat terjadi karena auditor independen harus mengikuti standar profesional yag diatur di dalam SPAP, yang mewajibkan setiap akuntan publik harus mengikuti prosedur pada saat melakukan audit laporan keuangan suatu perusahaan. Sehingga rasio solvabilitas perusahaan tidak menjadikan auditor untuk mempercepat atau memperlambat proses audit yang akan dilakukannya.

Hal ini dibuktikan pada PT Bank Perdana Tbk tingkat solvabilitas 50,66\% dengan Audit Delay 85 hari (nilai di atas rata-rata 59,78). Sedangkan pada PT Bank Bukopin Tbk tingkat solvabilitas 8,17\% dengan Audit Delay 90 hari (nilai diatas rata-rata 59,78). Artinya tingkat solvabilitas yang tinggi maupun rendah sama-sama nilai audit delay diatas rata-rata. Hal tersebut yang mengakibatkan solvabilitas tidak berpengaruh terhadap Audit Delay. 
Penelitian ini juga sejalan dengan Wulantoro (2010) yang menyatakan Solvabilitas tidak berpengaruh terhadap Audit Delay namun tidak sejalan dengan hasil penelitian Candraningtiyas (2017), Wahyuningsih (2015) yang menyatakan bahwa Solvabilitas yang diiukur dengan CAR berpengaruh negatif signifikan terhadap Audit Delay.

\section{Pengaruh Faktor Internal Auditor Internal terhadap Audit Delay}

Berdasarkan dari hasil uji Hipotesis untuk pengaruh Internal Auditor terhadap Audit Delay, bahwa Internal Auditor tidak berpengaruh terhadap audit delay. Hal ini ditunjukkan dengan nilai signifikan $0,465>0,05$ Artinya bahwa Internal Auditor tidak dapat mempengaruhi Audit Delay.

Hasil penelitian ini menujukkan tidak adanya pengaruh Internal Auditor terhadap Audit Delay, Audit Delay tidak dapat dipengaruhi oleh Internal Auditor, auditor independen dan KAP yang baik tentunya akan melakukan pekerjaan audit secara profesional dan sesuai standar yang telah diatur oleh IAI. Sehingga Internal Auditor tidak dapat mempengaruhi panjang pendeknya serta ketepatan waktu dalam penyampaian laporan keuangan. Penelitian ini sejalan dengan penelitiannya Wiryakriyana dan Widhiyani (2017) menyatakan bahwa Internal Auditor tidak berpengaruh terhadap audit delay.

\section{Pengaruh Faktor Internal Ukuran Perusahaan terhadap Audit Delay}

Berdasarkan hasil uji hipotesis untuk pengaruh ukuran perusahaan terhadap audit delay menunjukkan bahwa ukuran perusahaan tidak berpengaruh terhadap Audit Delay. Hal ini ditunjukkan dengan nilai signifikan 0, $456>0,05$. Hal ini berarti besar atau kecilnya Ukuran Perusahaan tidak dapat mempengaruhi Audit Delay.

Tidak adanya pengaruh Ukuran Perusahaan diperkirakan karena sampel yang dipakai dalam penelitian ini adalah perusahaan yang sudah terdaftar di Bursa Efek Indonesia, dimana perusahaan tersebut memiliki kewajiban yang harus dipenuhi sesuai dengan ketentuan yang telah ditetapkan dalam peraturan penyampaian laporan keuangan tahunan. Sehingga tidak memperdulikan apakah perusahaan itu besar atau kecil, perusahaan tersebut sudah pasti diperhatikan atau dapat diakses dengan mudah laporan keuangannya oleh investor, pengawas permodalan dan pemerintah. Maka dari itu, semua perusahaan akan berusaha untuk melaporkan laporan keuangannya lebih cepat dari perusahaan lain guna menarik perhatian investor, dan tidak terkena sanksi dari badan pengawas permodalan dan pemerintah.

Hal ini dibuktikan pada PT Bank Mestika Dharma Tbk memiliki tingkat ukuran perusahaan sebesar 30,10 dengan Audit Delay selama 87 hari (diatas data-rata 59,78) 
sedangkan pada PT Bank Ganesha Tbk memiliki tingkat ukuran perusahaan sebesar 14,50 dengan Audit Delay selama 63 hari (diatas rata-rata 59,78). Artinya ketika ukuran perusahaan rendah maupun tinggi sama-sama nilai audit delay diatas rata-rata. Hal tersebut yang menyebabkan Audit Delay tidak berpengaruh terhadap Audit Delay.

Hasil penelitian ini mendukung hasil penelitian Prameswari dan Yustriante (2015), Anggradewi dan Haryanto (2014) yang menyatakan bahwa Ukuran Perusahaan tidak berpengaruh terhadap Audit Delay. Namun tidak sejalan dengan hasil penelitian Kurniawati (2018), dan Apriliane (2015) yang menyatakan bahwa ukuran perusahaan berpengaruh signifikan terhadap Audit Delay.

\section{Pengaruh Faktor Eksternal Ukuran KAP terhadap Audit Delay}

Berdasarkan hasil uji hipotesis untuk faktor eksternal pengaruh Ukuran KAP terhadap Audit Delay menunjukkan bahwa ukuran KAP berpengaruh negatif signifikan terhadap Audit Delay, hal ini dapat nilai $\mathrm{t}-2,520$ dengan nilai signifikansi $0,015<0,05$ artinya ukuran KAP berpengaruh negatif signifikan terhadap Audit Delay.

Ukuran KAP memiliki pengaruh negatif yang signifikan terhadap Audit Delay, disebabkan karena KAP yang memiliki reputasi yang baik seperti halnya KAP Big Four cenderung melakukan pekerjaan audit dengan baik karena dalam melakukan pekerjaan, bersikap profesional dan sesuai standar yang diatur oleh IAI. Penelitian ini sejalan dengan penelitian Hilmi (2008), Dwi Hayu Estrini dan Herry Laksito (2013) mengemukakan bahwa Ukuran KAP berpengaruh negatif terhadap Audit Delay, tetapi penelitian ini tidak sejalan dengan Andi Kartika (2008) bahwa Ukuran KAP tidak mempunyai pengaruh terhadap Audit Delay.

\section{Pengaruh Faktor Internal Solvabilitas Terhadap Timeliness}

Berdasarkan hasil uji Hipotesis pengaruh Solvabilitas terhadap Timeliness bahwa Solvabilitas tidak berpengaruh terhadap Timeliness, hal ini ditunjukkan dengan nilai signifikan 0, 671 > 0,05 Artinya bahwa tinggi rendahnya solvabilitas yang diukur dengan DER tidak dapat mempengaruhi Timeliness.

Hasil penelitian ini menujukkan tidak adanya pengaruh solvabilitas perusahaan terhadap ketepatwaktuan penyampaian laporan keuangan hasil audit. Hal ini dapat terjadi karena auditor independen harus mengikuti standar profesional yag diatur di dalam SPAP, yang mewajibkan setiap akuntan publik harus mengikuti prosedur pada saat melakukan audit laporan keuangan suatu perusahaan. Sehingga rasio solvabilitas perusahaan tidak menjadikan 
auditor untuk mempercepat atau memperlambat proses penyampaian pelaporan keuangan hasil audit.

\section{Pengaruh Faktor Internal Auditor Internal terhadap Timeliness}

Berdasarkan dari hasil uji Hipotesis untuk pengaruh Internal Auditor terhadap Timeliness, bahwa Internal Auditor tidak berpengaruh terhadap Timeliness. Hal ini ditunjukkan dengan nilai negative signifikan $0,974>0,05$ Artinya bahwa Internal Auditor tidak dapat mempengaruhi Timeliness.

Hasil penelitian ini menujukkan tidak adanya pengaruh Internal Auditor terhadap Timeliness, Timeliness tidak dapat dipengaruhi oleh Internal Auditor. Ada maupun tidaknya Internal Auditor penyampaian laporan keuangan auditan akan segera disampaikan berkenaan dengan ketepatan waktu dalam penyampaian laporan keuangan.

\section{Pengaruh Internal Ukuran Perusahaan terhadap Timeliness}

Berdasarkan hasil uji hipotesis untuk pengaruh ukuran perusahaan terhadap Timeliness menunjukkan bahwa ukuran perusahaan tidak berpengaruh terhadap Timeliness. Hal ini ditunjukkan dengan nilai signifikan 0,403 > 0,05. Hal ini berarti besar atau kecilnya Ukuran Perusahaan tidak dapat mempengaruhi Timeliness.

Tidak adanya pengaruh Ukuran Perusahaan diperkirakan karena perusahaan yang sudah terdaftar di Bursa Efek Indonesia memiliki kewajiban yang harus dipenuhi sesuai dengan ketentuan yang telah ditetapkan dalam peraturan penyampaian laporan keuangan tahunan. Sehingga tidak memperdulikan apakah perusahaan itu besar atau kecil, perusahaan tersebut sudah pasti diperhatikan atau dapat diakses dengan mudah laporan keuangannya oleh investor, pengawas permodalan dan pemerintah. Maka dari itu, semua perusahaan akan berusaha untuk melaporkan laporan keuangannya lebih cepat dari perusahaan lain guna menarik perhatian investor, dan tidak terkena sanksi dari badan pengawas permodalan dan pemerintah.

\section{Pengaruh Eksternal Ukuran KAP terhadap Timeliness}

Berdasarkan hasil uji hipotesis untuk pengaruh faktor eksternal Ukuran KAP terhadap Timeliness menunjukkan bahwa ukuran KAP berpengaruh negatif tidak signifikan terhadap Timeliness, hal ini dapat nilai t $-0,248$ dengan nilai signifikansi $0,805<0,05$ artinya ukuran KAP berpengaruh negatif tidak signifikan terhadap Timeliness. 
Ukuran KAP memiliki pengaruh negatif yang signifikan terhadap Timeliness, disebabkan karena KAP yang memiliki reputasi yang baik seperti halnya KAP Big Four cenderung melakukan pekerjaan audit dengan baik karena dalam melakukan pekerjaan, bersikap profesional sehingga penyampaian laporan keuangan auditan akan segera disampaikan.

\section{Pengaruh Faktor Internal yang dimoderasi Profitabilitas terhadap Audit Delay}

Berdasarkan hasil uji statistik nilai R2 yang pertama sebesar 0,149 atau 14,9\%, setelah ada persamaan regresi kedua nilai R2 turun menjadi 0,057 atau 5,7\%. Dengan melihat hasil diatas maka dapat disimpulkan bahwa Profitabilitas bukan sebagai variabel moderating, artinya bahwa Profitabilitas tidak memoderasi hubungan antara DER, Internal Auditor dan Ukuran Perusahaan dengan Audit Delay, sehingga hipotesis Ha.3 yang mengatakan bahwa faktor internal DER Internal Auditor dan Ukuran Perusahaan berpengaruh terhadap Audit Delay yang dimoderasi oleh Profitabilitas ditolak.

Hasil penelitian ini sejalan dengan penelitian (Ni Luh Made Winda Pratiwi dan Maria M. Ratna Sari, 2017) dan (Kusuma, Budi Hartono, dan Novice Lianto, 2010) yang menyatakan bahwa baik perusahaan besar atau kecil yang profitabilitasnya tinggi tidak akan menunda penyampaian berita baik tersebut kepada publik. Perusahaan yang telah mendapatkan opini auditor akan langsung menyampaikan good news tersebut ke investor ataupun pihak berkepentingan lainnya, baik itu dilakukan oleh kantor akuntan publik The Big Four ataupun Non The Big Four karena setiap KAP melakukan audit sesuai dengan Standar Profesional Akuntan Publik (SPAP).

\section{Pengaruh Faktor Internal yang dimoderasi Profitabilitas terhadap Timeliness}

Berdasarkan hasil uji statistik nilai R2 yang pertama sebesar 0,30 atau 3\%, setelah ada persamaan regresi kedua nilai R2 turun menjadi 0,029 atau 2,9\%. Dengan melihat hasil diatas maka dapat disimpulkan bahwa Profitabilitas bukan sebagai variabel moderating.

Artinya bahwa Profitabilitas tidak memoderasi hubungan antara DER, Internal Auditor dan Ukuran Perusahaan dengan Timeliness, sehingga hipotesis Ha.3 yang mengatakan bahwa faktor internal DER Internal Auditor dan Ukuran Perusahaan berpengaruh terhadap Timeliness yang dimoderasi oleh Profitabilitas ditolak. Penelitian ini sejalan dengan Apriyana (2017) yang menunjukan Profitabilitas tidak berpengaruh terhadap Timeliness. Perusahaan dengan Profitabilitas yang tinggi maupun rendah mempunyai kewajiban untuk menyampaikan laporan keuangan auditan tepat waktu. Hal ini dikarenakan menurut 
Keputusan Ketua Badan Pengawas Pasar Modal (Bapepam) dan Laporan Keuangan (LK) tentang Penyajian Laporan Keuangan menyatakan bahwa perusahaan go public yang terdaftar di Bursa Efek Indonesia (BEI) wajib menyampaikan laporan keuangan tahunan yang disertai dengan laporan auditor independen kepada Bapepam dan LK serta mengumumkan kepada masyarakat paling lambat pada akhir bulan ketiga atau 90 hari setelah tahun tutup buku berakhir. Apabila perusahaan go public tersebut terlambat menyampaikan laporan keuangan, maka akan dikenakan sanksi sesuai dengan peraturan yang telah ditetapkan oleh Bapepam. Hal tersebut menandakan bahwa perusahaan dengan Profitabilitas tinggi maupun rendah berusaha untuk menyampaikan laporan keuangannya tepat waktu guna mencegah sanksi yang akan diberikan Bapepam apabila terlambat menyampaikannya. Namun berbeda dengan penelitian kurniawati (2015), Wulantoro (2010) dan Estrini (2013) bahwa profitabilitas berpengaruh terhadap Timeliness

\section{KESIMPULAN}

Faktor Internal Solvabilitas, internal auditor, ukuran perusahaan, tidak berpengaruh Terhadap Audit Delay, ini menunjukan bahwa tingginya solvabilitas tidak mengakibatkan waktu penyelesaian audit semakin lama, dikarenakan auditor independen harus mengikuti standar profesional yag diatur di dalam SPAP. Audit Delay tidak dapat dipengaruhi oleh Internal Auditor, auditor independen dan KAP yang baik tentunya akan melakukan pekerjaan audit secara profesional dan sesuai standar yang telah diatur oleh IAI.

Sementara itu Ukuran KAP memiliki pengaruh negatif yang signifikan terhadap Audit Delay, disebabkan KAP yang memiliki reputasi yang baik seperti halnya KAP Big Four cenderung melakukan pekerjaan audit dengan baik. Tidak adanya pengaruh ukuran Perusahaan diperkirakan karena sampel yang dipakai dalam penelitian ini adalah perusahaan yang sudah terdaftar di Bursa Efek Indonesia, dimana perusahaan tersebut memiliki kewajiban yang harus dipenuhi sesuai dengan ketentuan yang telah ditetapkan dalam peraturan penyampaian laporan keuangan tahunan. Sehingga tidak memperdulikan apakah perusahaan itu besar atau kecil, perusahaan tersebut sudah pasti diperhatikan atau dapat diakses dengan mudah laporan keuangannya oleh investor, pengawas permodalan dan pemerintah. Maka dari itu, semua perusahaan akan berusaha untuk melaporkan laporan keuangannya lebih cepat dari perusahaan lain guna menarik perhatian investor, dan tidak terkena sanksi dari badan pengawas permodalan dan pemerintah. 
Pengaruh Faktor Internal Solvabilitas, Auditor Internal, Ukuran Perusahaan, tidak berpengaruh Terhadap Timeliness. Tidak adanya pengaruh solvabilitas perusahaan terhadap ketepatwaktuan penyampaian laporan keuangan hasil audit., karena auditor independen harus mengikuti standar profesional yag diatur di dalam SPAP, yang mewajibkan setiap akuntan publik harus mengikuti prosedur pada saat melakukan audit laporan keuangan suatu perusahaan. Sehingga rasio solvabilitas perusahaan tidak menjadikan auditor untuk mempercepat atau memperlambat proses penyampaian pelaporan keuangan hasil audit.

Timeliness tidak dapat dipengaruhi oleh Internal Auditor, ada maupun tidaknya Internal Auditor penyampaian laporan keuangan auditan akan segera disampaikan berkenaan dengan ketepatan waktu dalam penyampaian laporan keuangan. Ukuran Perusahaan diperkirakan karena perusahaan yang sudah terdaftar di Bursa Efek Indonesia memiliki kewajiban yang harus dipenuhi sesuai dengan ketentuan yang telah ditetapkan dalam peraturan penyampaian laporan keuangan tahunan. Sehingga tidak memperdulikan apakah perusahaan itu besar atau kecil, perusahaan tersebut sudah pasti diperhatikan atau dapat diakses dengan mudah laporan keuangannya oleh investor, pengawas permodalan dan pemerintah. Maka dari itu, semua perusahaan akan berusaha untuk melaporkan laporan keuangannya lebih cepat dari perusahaan lain guna menarik perhatian investor, dan tidak terkena sanksi dari badan pengawas permodalan dan pemerintah.

Ukuran KAP memiliki pengaruh negatif yang signifikan terhadap Timeliness, disebabkan karena KAP yang memiliki reputasi yang baik seperti halnya KAP Big Four cenderung melakukan pekerjaan audit dengan baik karena dalam melakukan pekerjaan, bersikap profesional sehingga penyampaian laporan keuangan auditan akan segera disampaikan.

\section{DAFTAR PUSTAKA}

Ahmad, R. A., \& Kamarudin, K. A. (2000). "Audit Delay And The Timeliness Of Corporate Reporting: Malaysian Evidence". MARA University Of Technology, Malaysia.

Aldie, R. R. (2012). Faktor-Faktor Yang Berpengaruh Terhadap Audit Delay (Studi Empiris Pada Perusahaan Manufaktur Yang Terdaftar Di Bursa Efek Indonesia Tahun 2008). Skripsi. Universitas Kristen Maranatha, Bandung.

Alvina, N. A. (2013). Pengembangan Model Audit Delay Dengan Audit Report Lag Dan Total Lag. Accounting Analysis Journal, Vol I, No 4. 
Amani, F. A. (2016). Pengaruh Ukuran Perusahaan, Profitabilitas, Opiniaudit, Dan Umur Perusahaan Terhadap Audit Delayaudit,. Skripsi. Fakultas Ekonomi Universitas Negeri Yogyakarta.

Apriliane, M. D. (2015). Analisis Faktor Yang Memperngaruhi Audit Delay. Skripsi. Fakultas Universitas Negeri Yogyakarta.

Apriyana, N. (2017). Pengaruh Profitabilitas, Solvabilitas, Ukuran Perusahaan, Dan Ukuran Kap Terhadap Audit Delay Pada Perusahaan Properti Dan Real Estate Yang Terdaftar Di Bursa Efek Indonesia Periode 2013-2015. Jurnal Nominal / Volume Vi Nomor 2, 108-124.

Ardianti, F. (2013). Analisis Faktor-Faktor Yang Berpengaruh Terhadap Audit Delay (Studi Pada Perusahaan Manufaktur Yang Terdaftar Di Bursa Efek Indonesia). Skripsi. Fakultas Ekonomika Dan Bisnis Universitas Diponegoro Semarang.

Ashton, R., Willingham, J., \& Elliot, R. (1987). An Empirical Analysis Of Audit Delay. Journal Of Accounting Reserarch.

Azhari, M., Wahidahwati, \& Ihsan, B. R. (2014). Faktor-Faktor Yang Mempengaruhi Audit Delay (Studi Kasus Pada Perusahaan Consumergoods Terdaftar Di Bursa Efek Indonesia). Jurnal Akuntansi. Vol. 3 No. 10 (2014).

Brigham, \& Houston. (2010). Dasar-Dasar Manajemen Keuangan Buku I (Edisi 2). Jakarta: Salemba Empat.

Candraningtiyas, E. G., Sulindawati, E. N., \& Wahyuni, M. A. (2017). Pengaruh Ukuran Perusahaan, Profitabilitas, Solvabilitas, Dan Ukuran Kantor Akuntan Publik Terhadap Audit Delay Pada Perusahaan Consumergoods Yang Terdaftar Di Bei Tahun 20122015. E-Journal S1 Ak Universitas Pendidikan Ganeshajurusan Akuntansi Program S1 (Vol: 8 No: 2 Tahun 2017).

Ghozali, I. (2011). “Aplikasi Analisis Multivariate Dengan Program SPSS”. Semarang: Badan Penerbit Universitas Diponegoro.

Miradhi, J. M. (2016). Ukuran Perusahaan Sebagai Pemoderasi Pengaruh Profitabilitas Dan Opini Auditor Pada Audit Delay . E-Jurnal Akuntansi Universitas Udayana, 388-415.

Mulyadi. (2010). Auditing Cetakan Ke-6. Jakarta: Salemba Empat.

Panjaitan, Z. F., Wadidahwati, \& Amanah, L. (2013). Faktor-Faktor Yang Mempengaruhi Audit Delay Dan Timeliness Atas Penyampaian Laporan Keuangan. Jurnal Ilmu \& Riset Akuntans, Vol.2 No 11 Surabaya : Sekolah Tinggi Ilmu Akuntansi Indonesia.

Parameswari, T. (2012). Analisis Faktor-Faktor Yang Mempengaruhi Terjadinya Audit Delay Pada Perusahaan Consumer Good Industry Di Bursa Efek Indonesia (Periode Tahun 2008-2010), Skripsi. Universitas Kristen Manaratha.

Prameswari, A. S., \& Yustrianthe, R. H. (2015). Analisis Faktor-Faktor Yang Memengaruhi Audit Delay (Studi Empiris Pada Perusahaan Manufaktur Yang Terdaftar Di Bursa Efek Indonesia. Junal Akuntansi/ Volume XIX, No.01, Januari 2015 : 50-67. 
Saemargani, F. I., \& Mustikawati, I. (2015). Pengaruh Ukuran Perusahaan, Umur Perusahaan, Profitabilitas, Solvabilitas, Ukuran KAP Dan Opini Auditor Terhadap Audit Delay. Jurnal Nominal/Volume IV Nomor 2.

Suarsa, A. (2015). Pengaruh Profitabilitas, Solvabilitas dan Opini Audit. 1-9.

Sugiyono. (2014). Metode Penelitian Pendidikan Pendekatan Kuantitatif. Bandung: Alfabeta.

Verawati, W. N. (2016). Pergantian Auditor, Reputasi Kap, Opini Audit Dan Komite Audit Pada Audit Delay. E-Jurnal Akuntansi Universitas Udayana, 1083-1111.

Wahyuningsih, S. (2015). Pengaruh Ukuran Perusahaan, Umur Perusahaan, Profitabilitas, dan Solvabilitas Terhadap Audit Delay (Studi Pada Perusahaan Consumergoods Yang Terdaftar Di BEI). E-Journal Ekonomi Bisnis Dan Akuntansi, 1-12. 